\title{
CEDERA LIGAMEN KRUSIATUM ANTERIOR
}

\author{
Selly Wijayasurya ${ }^{1}$, Tjie Haming Setiadi² \\ ${ }^{1}$ Fakultas Kedokteran, Universitas Tarumanagara Jakarta \\ Email: tjies@fk.untar.ac.id \\ ${ }^{2}$ Fakultas Kedokteran, Universitas Tarumanagara Jakarta \\ Email: tjies@fk.untar.ac.id
}

Masuk : 10-03-2021, revisi: 28-04-2021, diterima untuk diterbitkan : 29-05-2021

\begin{abstract}
ABSTRAK
Cedera ligamen krusiatum anterior (ACL) merupakan salah satu dari cedera olahraga yang cukup sering terjadi, terutama pada individu berusia antara 20 hingga 40 tahun, dengan frekuensi 2 hingga 8 kali lipat lebih banyak pada perempuan dibanding laki-laki. Cedera ligamen krusiatum anterior dapat terjadi akibat kontak ataupun non-kontak. Cedera ligamen diklasifikasikan sebagai ringan, sedang, dan berat; tergantung dari integritas jaringan lunak dan derajat instabilitas sendi. Penentuan derajat cedera ligamen penting dalam menentukan jenis terapi yang dibutuhkan, prognosis penyembuhan anatomis dan fungsional; perlu tidaknya operasi, serta lamanya program rehabilitasi yang dibutuhkan.
\end{abstract}

Kata Kunci: ACL, Cedera Olahraga, Cidera Ligament

\begin{abstract}
Anterior cruciate ligament (ACL) injuries are common, especially in young individuals who participate in sports activities, aging 20 to 40 years old, with double to eight times increasing probability of incidence in women compared to men. The ACL injuries can result from direct or contact and non-contact injuries. The ACL injuries can be varied in severity, from mild to severe cases. Establishing the severity of injuries is important for determining the apppropriate management, its prognosis both for anatomical and functional healing, as well as the need of surgical or reconstruction treatment and the duration of rehabilitation program.
\end{abstract}

Keywords: ACL, Ligament Injuries, Sport Injuries

\section{PENDAHULUAN}

Lutut merupakan salah satu sendi yang cukup kompleks pada tubuh manusia. Karena banyaknya olahraga ekstrim yang menempatkan beban pada lutut, maka sendi lutut menjadi salah satu sendi yang paling sering mengalami trauma. Lutut didesain terutama untuk memberikan stabilitas pada penumpuan beban ("weight bearing") serta mobilitas dalam pergerakan atau lokomosi. Bersama dengan panggul dan pergelangan kaki, lutut menopang tubuh saat berdiri dan aktivitas fungsional primer seperti berjalan, memanjat, serta duduk. ${ }^{1,2}$

Cedera ligamen terjadi paling banyak pada individu berusia antara 20 hingga 40 tahun; umumnya terjadi sebagai akibat dari cedera olahraga seperti sepak bola, basket, voli, senam, dll. Cedera pada lutut harus dipandang sebagai suatu kasus yang berpotensi serius karena stabilitas pasif sendi akan dapat terganggu. Umumnya lebih dari satu ligamen akan rusak, namun yang paling sering terkena dan yang paling serius cedera pada adalah ligamen krusiatum anterior (ACL, "anterior cruciatum ligament"). Lebih dari 250.000 kasus cedera ACL terjadi di Amerika setiap tahunnya, atau satu pada 3000 orang. Frekuensi cedera ACL pada perempuan lebih banyak 2 hingga 8 kali lipat daripada laki-laki. ${ }^{2,3,4}$

\section{CEDERA LIGAMEN KRUSIATUM ANTERIOR}

Ligamen krusiatum anterior (ACL) merupakan salah satu ligamen pada lutut yang paling sering cedera. Cedera dapat terjadi akibat kontak ataupun non-kontak. Mekanisme kontak yang paling sering adalah hentakan pada bagian lateral lutut, sehingga memberikan gaya valgus pada lutut, 
yang dapat berakibat bukan hanya cedera pada ACL, namun juga pada struktur lutut yang lain, yang disebut sebagi triad O'Donoghue. Mekanisme non-kontak adalah akibat gerakan rotasional dimana tibia berputar secara eksternal pada kaki yang menapak, seperti pada pemain ski, saat jatuh dimana bagian pinggir dalam papan ski tertancap pada es, sehingga lutut dalam keadaan rotasi eksterna dan valgus (gambar 1). Cedera tunggal terjadi saat kaki bawah berputar sementara telapak kaki menapak (gambar 2). 2, 5, 6

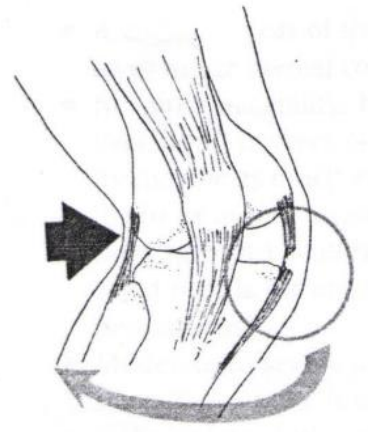

Gambar 1

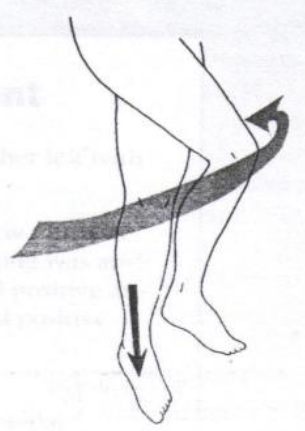

Gambar 2

Mekanisme non-kontak yang lain misalnya akibat deselerasi cepat atau tiba-tiba yang memberikan gaya pada bagian anterior tibia sehingga otot kuadriseps berkontraksi secara maksimal dan mendadak, seperti pada pemain basket atau sepak bola yang berhenti secara mendadak dan merubah arah tubuhnya. Hiperekstensi dari anterior lutut dengan lutut yang menapak dapat merobek ACL (gambar 3), bila cukup berat dapat pula merobek ligamen kolateral medial (MCL). Sedangkan gaya dorong varus dengan tibia dalam keadaan rotasi interna dapat merobek ligamen kolateral lateral (LCL); pada beberapa kasus dapat pula merobek ligamen krusiatum dan perlekatan iliotibial band dan otot biseps pada paha (gambar 4). ${ }^{1,2}$

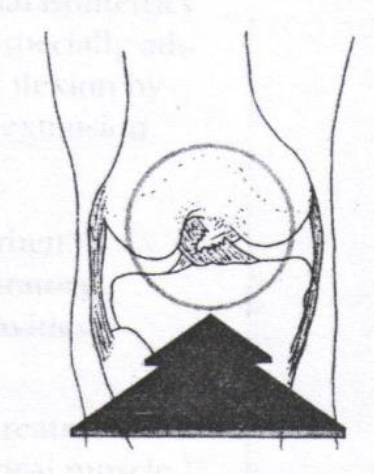

Gambar 3

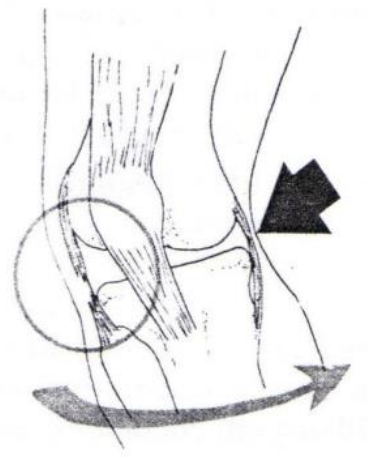

Gambar 4

Penentuan derajat cedera ligamen penting dalam menentukan terapi awal yang diperlukan serta prognosis sebagai suatu hal yang diperlukan dalam penyembuhan fungsional; perlu tidaknya operasi, serta lamanya rehabilitasi yang dibutuhkan. Cedera ligamen diklasifikasikan sebagai ringan, sedang, dan berat; namun kadang klasifikasi ini tumpang tindih serta tergantung pada pengalaman pemeriksa. Secara umum klasifikasi cedera adalah sebagai berikut: ${ }^{7,8}$

1. Ringan: beberapa serat robek namun integritas ligamen tetap utuh dan sendi tetap stabil.

2. Sedang: serat robek dalam kuantitas yang cukup untuk mengurangi fungsi ligamen, namun stabilitas otot tetap dapat terjaga. Beberapa gerak sendi yang berlebih dapat dilihat bila dibandingkan dengan sisi yang sehat.

3. Berat: serat ligamen robek komplit dengan hilangnya integritas sendi; instabilitas sendi nampak jelas pada derajat cedera ini. 


\section{METODE PENELITIAN}

\section{RESPON KARTILAGO TERHADAP IMOBILISASI \& ROBEKNYA ACL}

Cedera ligamen dan imobilisasi sendi menyebabkan gangguan atau hilangnya kondisi fisiologi normal sendi, tulang, dan kartilago. Perubahan atrofik dari jaringan musculoskeletal selalu terjadi saat fungsi tubuh terganggu atau hilang. Secara klinis, cedera ligamen, dalam hal ini cedera ACL, akan membuat instabilitas sendi, sementara imobilisasi akan menyebabkan hilangnya gerakan atau fungsi normal sendi sebagai penahan beban, paralisis atau amputasi tungkai, serta kombinasinya. Caterson dan Lowther serta Palmoski dkk menemukan bahwa setelah 6-8 minggu, meskipun penampilan umum kartilago normal, namun melalui pengukuran biokimiawi, didapati kadar prostaglandin (PG) sangat terganggu. Jalinan kolagen pada permukaan ACL rusak, yang dapat dilihat melalui hilangnya pewarnaan safranin $\mathrm{O}$ staining, yang menandai berkurangnya PG secara signifikan. Rusaknya jalinan kolagen juga menyebabkan edema, berkurangnya struktur mekanik lutut, serta materi pembawa beban yang dimiliki kartilago. Setelah cedera ACL, transmisi beban yang terganggu dapat menyeberangi sendi, dan akhirnya dapat menstimulasi rusaknya jaringan secara biologis dan biomekanik yang cukup berat sehingga muncullah yang dinamai osteoarthritis (OA) pada sendi yang cedera; termasuk remodeling tulang, eburnasi subkondral dan pembentukan osteofit pada pinggir sendi. Dekat permukaan sendi, nampak hilangnya PG tanpa efusi synovial dan osteofit. Gambaran radiografik menunjukkan demineralisasi tulang ringan. Semua ini menandai perubahan pada area kontak dan hilangnya gaya weight-bearing yang membuat perubahan atrofik pada kartilago sendi yang terimobilisasi. ${ }^{9}$

Dengan remobilisasi, kondrosit akan terstimulasi untuk meningkatkan produksi agrekan PG dan protein penyerta. Dengan adanya hialuronat, molekul-molekul ini bersatu membentuk agregat PG lagi, mencoba menjaga kartilago tetap dalam bentuk semula, meskipun proses ini kadang tidak sempurna. Beban mekanik berlebihan secara mendadak setelah fase imobilisasi, seperti berlari setelah pemakaian gips, juga mencegah perubahan atrofik pada kartilago lutut. Pada semua kasus, penyembuhan distimulasi dengan fungsi dan beban sendi yang tidak berlebih. ${ }^{9}$

Olahraga derajat sedang dipercaya dapat meningkatkan dan memfasilitasi proses penting fungsi kartilago yang normal. Komposisi dan struktur kartilago sendi dijaga melalui keseimbangan aktivitas anabolik dan katabolik oleh adanya kondrosit, yang memberikan respon terhadap sinyal yang muncul terhadap aktivitas sehari-hari yang menumpu beban pada tubuh, seperti jalan dan lari. Latihan yang distimulasi oleh pembebanan siklik telah menunjukkan respon biologis terhadap kartilago sendi berlawanan dengan perubahan yang terjadi pada degenerasi osteoartritis. $^{9}$

Pemeriksaan pada cedera ligamen krusiatum anterior dimulai dengan anamnesa secara teliti, terutama mengenai kecepatan energy serta arah tekanan pada saat cedera terjadi. Anamnesis juga berfungsi sebagai dasar tingkat keparahan cedera serta tipe cedera itu sendiri. Seorang atlit umumnya mengatakan adanya bunyi "pop" tiba-tiba pada lutut dan adanya sensasi 'lutut keluar'. Sekitar 50-70\% penderita cedera ACL mendengar atau merasakan bunyi "pop" ini. Kadangkadang bunyi tersebut dapat pula didengar oleh orang yang berada di sekitar penderita. Gejala penting lain adalah nyeri lutut anterior dengan nyeri pada garis sendi lateroposterior. Nyeri ini ekstrim pada saat terjadinya cedera, namun berkurang secara perlahan; dapat muncul lagi bila sendi digerakkan atau diberi beban. Adanya instabilitas lutut juga merupakan gejala yang cukup sering dikeluhkan. Pembengkakan awal dapat muncul, dan dalam waktu 24 jam didapati efusi yang signifikan. ${ }^{3-4,10,11}$ 
Pemeriksaan klinis harus dilakukan secara teliti. Adanya efusi, umumnya diakibatkan oleh hemartrosis dijumpai pada inspeksi yang kadang membuat sendi sulit untuk diperiksa. Hemartrosis ini harus selalu diaspirasi; bila perlu disuntikkan anestetika local terlebih dulu untuk membantu evaluasi sendi lebih lanjut. Perhatikan adanya memar pada atau di sekitar ligamen ataupun adanya tanda inflamasi. ${ }^{3,11}$ Pada palpasi, lakukan palpasi seputar garis sendi lutut dan seluruh jalur ligamen; tandai lokasi nyeri. Nyeri pada cedera ACL bervariasi dan dapat dihubungkan dengan adanya robekan meniscus dan frakrtur avulsi. Bengkak akibat efusi atau penyebaran darah sepanjang jalur ligamen juga dapat dirasakan saat palpasi. ${ }^{3}$

Periksa adanya keterbatasan lingkup gerak sendi lutut. Nyeri pada pergerakan atau keterbatasan gerak dapat menjadi tanda adanya cedera meniskus. Pemeriksaan stabilitas lutut penting untuk mengevaluasi adanya instabilitas. Sejumlah tes khusus dilakukan untuk memeriksa integritas ligamen krusiatum, seperti anterior drawer test, Lachman drawer test, pivot-shift test, jerk test, dan flexion-rotation drawer test. ${ }^{1,3,5,10}$ Tes anterior drawer dilakukan bila dicurigai cedera pada ligamen krusiatum atau kolateral. Pasien berbaring supine dengan kaki difleksikan $90^{\circ}$; jari-jari pemeriksa diletakkan pada rongga poplitea, dengan ibu jari pada garis sendi medial dan lateral, sedangkan telunjuk pada tendon hamstring. Gerakan tibia ke depan yang berlebihan terhadap femur mengindikasikan adanya cedera pada MCL dan atau ACL. ${ }^{1,3}$

Tes anterior drawer dengan sendi lutut pada sudut $20-30^{\circ}$ dikenal sebagai tes Lachman's. tes ini digunakan untuk memeriksa integritas ACL. Satu tangan menstabilisasi kaki dengan memegang bagian distal paha, sementara tangan yang lain memegang bagian proksimal tibia dan mencoba menggerakkannya ke anterior. Bagian bawah diangkat ke depan, dan tanda anterior drawer yang positif dapat dilihat dan dirasakan, sehingga mengindikasikan adanya robekan pada ACL. 1,3,5,8 Tes pivot shift didesain untuk memeriksa instabilitas rotasi anterolateral. Tes ini lebih sering digunakan pada kondisi kronik dan merupakan tes yang cukup sensitif bila terdapat robekan ACL. Dengan lutut yang diekstensikan, lutut ditekan ke arah dalam (dalam keadaan valgus) selama fleksi pasif dan rotasi interna dari tungkai bawah. Pada fleksi $20-30^{\circ}$, subluksasi ke depan dari kondilus tibia dapat terlihat. Dengan fleksi lebih jauh hingga 40-60', kondilus lateral akan berkurang, dan atlit akan merasakan fenomena 'giving way'. Kebalikan urutan ini dinamai 'jerk test', dengan titik awal dalam posisi fleksi. ${ }^{1,3}$

Tes flexion rotation drawer dilakukan dengan tungkai bawah dipegang dalam posisi fleksi antara 15 dan $30^{\circ}$. Pada posisi $15^{\circ}$, tibia disubluksasikan ke anterior dengan femur rotasi eksterna. Saat lutut difleksikan ke $30^{\circ}$, tibia berputar ke posterior dan femur ke posisi rotasi interna. ${ }^{1}$

Pemeriksaan x-ray sendi lutut harus dilakukan untuk mengkonfirmasi atau mengeksklusikan adanya cedera pada tulang, seperti lepasnya fragmen tulang pada titik insersi ligamen tersebut. Foto x-ray mungkin menunjukkan adanya fraktur avulsi ataupun insersi ACL ke tibia atau ke margin kapsular lateral dari tibia. Artrosintesis dapat dilakukan untuk mengurangi tekanan dan nyeri; dapat dijumpai cairan serous ataupun darah di dalam robekan ACL. tears. Akurasi magnetic resonance imaging (MRI) sekitar 85-90\%, sementara artroskopi hampir 100\% akurat. ${ }^{3}$, 10

\section{HASIL DAN PEMBAHASAN PENATALAKSANAAN}

Setelah diagnosis robekan ACL tegak, harus segera direncanakan tindakan penatalaksanaan berdasarkan tingkat cedera, keinginan penderita untuk berolahraga di kemudian hari, serta kondisi kerja dan sosialnya. Intervensi yang diambil haruslah ditujukan untuk mencapai tujuan spesifik yang dihubungkan dengan impairment, limitasi fungsional, serta disabilitasnya. ${ }^{10-12}$ 


\section{Tatalaksana non-operatif}

Segera setelah cedera, istirahatkan lutut dengan splint sebagai sarana untuk memproteksi sendi selama 24-48 jam. Pada fase akut, istirahatkan kaki dalam posisi elevasi, yakni bagian yang cedera diletakkan lebih tinggi dari bagian tubuh yang lain. Hal ini akan mengurangi aliran darah dan memperbaiki drainase, sehingga pembengkakan yang terjadi lebih minimal, dan mengurangi beban pada bagian yang rusak. Selama fase ini, aplikasi kantong es dapat mengontrol bengkak, mengurangi nyeri, dan membantu program rehabilitasi aktif. Setelah fase penyembuhan akut terlewati, latihan harus ditujukan untuk mencapai lingkup gerak sendi yang normal, control balans, normalisasi gait, dan penguatan otot pendukung dan penstabilisasi sendi selama aktivitas fungsional. Pada hari keempat, fisioterapi dilakukan dengan media panas, terapi kolam, dan latihan mobilisasi tunggal. $2,3,13$

Jika perbaikan operatif primer bukan menjadi pilihan, maka perlu ditentukan program rehabilitasi yang jelas. Derajat instabilitas dengan robekan ligamen akan mempengaruhi keinginan pasien untuk kembali ke aktivitas semula. Untuk menjaga performa fungsional otot, latihan perlu dikonsentrasikan kepada otot-otot paha. Latihan ini perlu dilakukan, meskipun tungkai dalam keadaan digips. Latihan terpeutik seperti aktivitas lingkup gerak sendi aktif dan pasif dalam lingkup yang senyaman mungkin dapat melumasi permukaan sendi dan membangtu resorbsi cairan sendi yang berlebih. Latihan reedukasi neuromuskuler seperti quadriceps setting, hamstrings setting, dan bemacam teknik lainnya dapat menjaga kemampuan otot dalam bereaksi, yang diperlukan dalam normalisasi pola gerak. Dalam melatih otot kuadriseps dilakukan latihan penguatan isometric dan quadriceps faradism. Latihan di rumah harus meliputi latihan untuk memfasilitasi peningkatan lingkup gerak sendi dan reedukasi neuromuskuler untuk mempercepat perbaikan klinis. $2,3,10,13$

Kolam merupakan media yang paling baik dalam meningkatkan mobilitas, menormalisasi gait, meningkatkan balans dan meningkatkan kekuatan otot. Berjalan, latihan kelenturan fisiologis, latihan menendang, menjinjit, balans dengan satu kaki, dan jongkok dapat dilakukan dengan mudah di kolam. Seiring perbaikan fase akut, derajat latihan dapat ditingkatkan dengan lebih baik. Latihan ambulasi yang progresif dengan atau tanpa alat bantu merupakan sarana primer untuk kembali ke aktivitas normal. Latihan rantai tertutup (closed chain) di darat seperti seluncur di tembok, minisquat, step-ups, stair stepping, dan leg press dapat memfasilitasi aktivitas fungsional seperti menaiki tangga, bangun dari kursi, dan keluar-masuk mobil. Latihan balans dan koordinasi dengan steps-up, wobble board, single-leg pulleys, dan menjinjit tanpa alat bantu dapat membantu menjada reaksi keseimbangan. Untuk di rumah, dapat digunakan berat tubuh sebagai beban penahan pada tembok, squat, lunges, dan steps-up. ${ }^{13}$

Penumpuan beban diperbolehkan bila penderita merasa nyaman; pada 6 minggu, mobilisasi penuh harus tercapai, untuk memungkinkan pasien kembali ke aktivitas olahraga secara bertahap. Petunjuk jelas harus diberikan ke pasien yang mengalami cedera ligamen krusiatum yang hendak kembali ke aktivitas olahraganya. Olahraga seperti berlari, bersepeda, dan berenang aman untuk dilakukan; ski, seluncur, dan hoki juga dianggap cukup aman karena lutut tetap terjaga dalam posisi fleksi. Namun, olahraga yang melibatkan gerakan melompat, ekstensi lutut, memotong dan menggunting dapat terhambat bagi atlit pasca cedera. Basket, tenis, dan bisbol juga cukup sulit dilakukan dan dapat menjadi predisposisi cedera lanjut dan terjadinya episode "giving way" yang berulang. Bila hal ini terjadi, olahraga harus segera dihentikan dan pertimbangan stabilisasi operatif perlu dipikirkan jika karir olahraga ingin terus dilanjutkan. ${ }^{10}$ 


\section{Tatalaksana operatif}

Tatalaksana operatif cedera ACL membutukan komitmen dari penderita. Setelah operasi, dilakukan pemasangan gips (casting) periodic dan proteksi dengan menggunakan brace serta adanya periode non-weightbearing dengan bantuan tongkat (crutches). ${ }^{10}$

Beberapa indikasi operasi primer adalah sebagai berikut: ${ }^{10}$

- Robeknya MCL dan ACL merupakan indikasi absolute untuk rekonstruksi kedua ligament pada atlit.

- Robekan komplit, baik akut ataupun insufisiensi kronik ACL dengan avulse perlekatan tuberkel tibia dari ACL, yang disertai periode instabilitas ataupun buckling lutut juga harus dioperasi per primum.

- Untuk memperbaiki robekan parsial ACL dengan adanya keterbatasan aktivitas fungsional dan lutut yang tidak stabil pada atlit, ditandai oleh instabilitas pivot shift yang positif.

- Robekan pada atlit muda yang ingin kembali ke olahraga kompetitif serta atlit usia tua yang memiliki waktu yang cukup untuk periode operasi dan rehabilitasi penuh.

- Tatalaksana konservatif robekan ACL yang gagal. ${ }^{2,10}$

Rekonstruksi ACL dapat dilakukan dengan beberapa pilihan graft yang berbeda; antara lain dengan menggunakan tendon patella, tendon hamstring, serta jaringan donor (allograft). Masingmasing pilihan memiliki beberapa keuntungan dan kerugian. ${ }^{14,15}$

Pasca operasi, penderita akan melalui fase-fase berikut ini: ${ }^{1}$

\section{KESIMPULAN DAN SARAN}

- $\quad$ Fase 1: cedera akut. Pada fase ini, tujuan utama adalah untuk meminimalisasi bengkak, nyeri, dan perdarahan pasca operasi; mencapai dan menjaga ekstensi lutut maksimal; kontrol kuadriseps yang baik; memulai fleksi lutut awal; serta mencapai kontrol neuromuskuler. Terapi RICE (Rest, Ice, Compression, dan Elevation) harus dilakukan untuk satu minggu pertama, 3 hingga 4 kali per hari. Stimulasi elektrikal otot dilakukan untuk mengkontrol nyeri dan menimbulkan kontraksi otot. Mesin kontak pasif dapat pula digunakan. Latihan rehabilitasi dilakukan untuk mencapai ekstensi penuh pada akhir minggu pertama. Latihan kuadriseps penting dilakukan seperti halnya straight leg raise dan fleksi isometrik submaksimal pada berbagai sudut 90,60 , dan $40^{\circ}$. Dapat pula dilakukan gerakan ekstensi lutut dalam 90 dan $30^{\circ}$; latihan panggul, khususnya gerakan aduksi; kontraksi isotonic hamstring aktif untuk mencapai fleksi $90^{\circ}$ dan mobilisasi patella. Perpindahan beban dilakukan dengan crutches, sedangkan tumpuan beban sesuai toleransi dalam brace dalam keadaan terkunci di posisi ekstensi penuh.

- $\quad$ Fase 2: fase penyembuhan, dengan perkiraan waktu 1 hingga 6 minggu. Tujuan fase ini adalah untuk mencapai pola jalan normal; menjaga ekstensi penuh; menguatkan kuadriseps dan hamstring; meningkatkan fleksi lutut; menjaga endurans kardiorespirasi dan memperbaiki kontrol neuromuskuler. Aktivitas fungsional ringan dapat dilakukan pada fase ini dengan ambulasi dalam brace terkunci di posisi ekstensi penuh. Brace dilepas pada minggu ketiga atau keempat; tumpuan beban pebuh pada akhir minggu keempat. Aktivitas proprioseptif dilakukan pada balance board. Lingkup gerak sendi penuh didapat sebelum atlit berlatih latihan penguatan intensif. Latihan rantai kinetik tertutup dan ko-kontraksi dilakukan dengan mengkonsentrasikan pada penguatan hamstring. Minisquats, step-ups, hamstring dan hip leg presses, serta fleksiekstensi lutut dalam posisi berdiri dalam gips juga harus dilakukan. Latihan sepeda stasioner segera setelah lingkup gerak sendi memungkinkan atau lakukan aktivitas naik-turun tangga.

- $\quad$ Fase 3: fase remodeling, dimulai pada minggu ke-7 hingga bulan ke-4 setelah cedera. Latihan dikonsentrasikan peningkatan fungsional secara progresif dan kembali ke aktivitas yang 
memerlukan kekuatan isokinetik dan kecepatan tinggi dengan menggunakan rubber tubing. Latihan keseimbangan dengan melompat dilakukan; sementara berlari pada bulan ke-4. Berikut adalah kriteria untuk kembali ke aktivitas olahraga kompetitif:

1. Lutut bebas gejala

2. Evaluasi isokinetik baik

3. Performa tes fungsional baik

4. Secara psikologis, atlit siap untuk bertanding kembali ${ }^{1}$

\section{REFERENSI}

${ }^{1}$ Arnheim, Daniel D. The Knee and Related Stuctures. In: Arnheim Danield. Principles of Athletic Training. 10 ${ }^{\text {th }}$ edition. Singapore: McGraw-Hill Book Co; 2000. p.515-64.

${ }^{2}$ Kisner Carolyn, Colby LA. The Knee. In: Kisner Carolyn, Colby LA. Therapeutic Exercise Foundations and Techniques. $4^{\text {th }}$ edition. Philadelphia: F. A. Davis Company; 2002. p.50662.

${ }^{3}$ Peterson Lars, Renström Per. Sports Injuries: Their Prevention and Treatment. Singapore: Kyodo Shing Loong Printing Industries Pte. Ltd.; 1988. p.286-301.

${ }^{4}$ Childs Sharon G. Pathogenesis of Anterior Cruciate Ligament Injury. From: Orthopedic Nursing. Jul/Aug 2002; Vol. 21, No. 4. ProQuest Medical Library. p.35.

${ }^{5}$ Platzer Werner. Atlas Berwarna \& Teks Anatomi Manusia Sistem Lokomotor Muskuloskeletal \& Topografi Jilid 1. Edisi 6. Jakarta: Penerbit Hipokrates; 1995.

${ }^{6}$ Neumann RD. Anterior Cruciate Ligament Injuries. In: Brown DE, Neumann RD. Orthopedic Secrets. Singapore: Hanley \& Belfus, Inc.: 1995. p.264-69.

${ }^{7}$ Cailliet Rene. Knee Pain and Disability. Philadelphia: F. A. Davis Company; 1973.

${ }^{8}$ Torg JS, Vegso JJ, Torg Elisabeth. Rehabilitation of Athletic Injuries: An Atlas of Therapeutic Exercise. USA: Year Book Medical Publishers. Inc.; 1987. p.92-110.

${ }^{9}$ Mow VC, Sugalski MT. Physiology of Synovial Joints and Articular Cartilage. In: Gonzalrz EG, Myers SJ, Edelstein JE, Lieberman JS, Downey JA. Downey \& Darling's Physiological Basis of Rehabilitation Medicine. 3rd edition. Boston: ButterworthHeinemann; 2001. p133-68.

${ }^{10}$ Welsh R Peter. Acute Injury to the Anterior Cruciate Ligament. In: Welsh RP, Shephard RJ. Current Therapy in Sports Medicine. Philadelphia: B.C. Decker Incorporated; 1985. p.24651.

${ }^{11}$ Cross Mervyn J. Anterior Cruciate Ligament Injuries: Treatment and Rehabilitation. [updated February 26, 1998]. Available from: http://www.sportsci.org/ency/aclinj/aclinj.html

${ }^{12}$ Anderson Chris. SportsMed. [updated 1998]. Available from: http://www.midwestpt.com/sportmed.htm

${ }^{13}$ Brody LT, Landel Robert. The Knee. In: Hall CM, Brody LT. Therapeutic Exercise Moving Toward Function. $2^{\text {nd }}$ edition. USA: Lippincott Williams \& Wilkins; 2005. p.488-523.

${ }^{14}$ Apley AG, Solomon Louis. Apley's System of Orrthopaedics and Fractures. London: Butterworth-Heinemann Ltd.: 1993.

${ }^{15}$ Cluett Jonathan. ACL Reconstruction. [updated June 2006]. Available from: http://orthopedics.about.com/cs/aclrepain/a/ aclgrafts.htm 